\title{
Influence of Selected Ecological Farming Practices on Soil Moisture Retention and Yield of Sorghum (Sorghum bicolor (L.) Moench) and Cassava (Manihot esculanta Crantz) in Semi-Arid Yatta Sub-County, Kenya
}

\author{
N. L. Namoi ${ }^{1}$, R. N. Onwonga ${ }^{1}$, G. N. Karuku ${ }^{1}$, C. M. Onyango ${ }^{2}$ \& V. M. Kathumo ${ }^{1}$ \\ ${ }^{1}$ Department of Land Resource Management and Agricultural Technology University of Nairobi, Nairobi, \\ Kenya \\ ${ }^{2}$ Department of Plant science and Crop protection University of Nairobi, Nairobi, Kenya \\ Correspondence: R. N. Onwonga, Department of Land Resource Management and Agricultural Technology, \\ University of Nairobi. P.O. Box 29053-00625, Nairobi, Kenya. Tel: 254-727-888-661. E-mail: \\ onwongarichard@gmail.com
}

Received: June 25, 2014 Accepted: July 13, 2014 Online Published: August 15, 2014

doi:10.5539/jas.v6n9p214 URL: http://dx.doi.org/10.5539/jas.v6n9p214

\begin{abstract}
In this study, the influence of ecological farming practices on soil moisture and yield of cassava (Manihot esculanta Crantz) and sorghum (Sorghum bicolor (L.) Moench) was investigated. The study was conducted in semi-arid Katangi and Ikombe divisions of Yatta sub-county between October 2010 and August 2012. A randomised complete block design with a split plot arrangement was used. Main plots were three cropping systems: (i) Intercropping; (Dolichos [Lablab purpureus]/Cassava, Dolichos/Sorghum, Pigeon pea [Cajanus cajan (L.) Millsp.]/Sorghum, Pigeon pea/Cassava); (ii) Rotation; Dolichos-Cassava, Dolichos-Sorghum, Pigeon pea-Cassava, Pigeon pea-Sorghum and (iii) Monocrop (pure cassava and sorghum). Split plots were organic inputs; farm yard manure (FYM), compost and absolute control. Sorghum/pigeon pea intercrop+FYM treatment had high moisture levels during short rain season (SRS) of 2010 at Katangi (5.21\%), SRS of 2011 at Ikombe $(5.19 \%)$ and long rain season (LRS) of 2011 at both sites $(5.83 \%, 12.30 \%)$. Grain yields were highest under sorghum/dolichos intercrop+ FYM during LRS of 2011 at Katangi (1.36 t ha $\left.{ }^{-1}\right)$ and Ikombe (1.48 $\left.\mathrm{t} \mathrm{ha} \mathrm{h}^{-1}\right)$, and SRS of 2010 at Katangi (1.39 $\left.\mathrm{t} \mathrm{ha}^{-1}\right)$ only. Cassava/dolichos intercrop recorded high soil moisture levels in both sites under sorghum/dolichos intercrop during SRS of $2010(6.48 \%, 8.35 \%)$, LRS of $2011(7.63 \%, 8.77 \%)$ and LRS of $2012(6.41 \%, 3.65 \%)$ for Katangi and Ikombe, respectively. Tuber yields were higher under

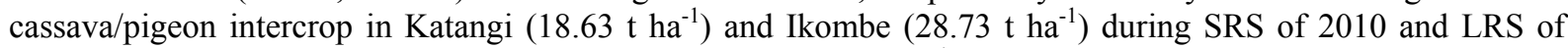
2011, and SRS of 2011 and LRS of 2012 at Katangi (20.86 $\left.\mathrm{t} \mathrm{ha}^{-1}\right)$. Intercropping sorghum with dolichos and cassava with pigeon pea + FYM would be a viable strategy to boost crop yields in smallholder farming systems of Yatta sub-county.
\end{abstract}

Keywords: compost, intercropping, Farm Yard Manure, moisture, organic inputs, rotation

\section{Introduction}

Low agricultural productivity presents a serious threat to food security in Sub Saharan Africa (SSA) where agricultural productivity needs to be increased by $4 \%$ annually by 2030 to keep up with population growth as opposed to the current 2\% rate (FAO, 1996). Soil moisture stress which, affects growth and development of crops (Agili \& Pardales, 1999; Akram, Sharhbaz, \& Ashraf, 2008; Ashraf, Nawazish, \& Athar, 2007), has been identified as the most limiting factor to land productivity in semiarid lands of Kenya (Itabari et al., 2004). In most of the Arid and Semi-arid lands (ASALs), low and often erratic rainfall, high rates of evaporation and in some cases, high atmospheric temperatures coupled with sandy soils which retain high amounts of heat and light create a difficult environment for crop growth (Lawson \& Sivakumar, 1991). Loss of soil moisture by evaporation and runoff alone has been estimated at 50\% and 10\% respectively (Kinama, Stigter, Ng'ang'a, \& Gichuki, 2005). This situation could be worsened by the effects of climate change (Funk et al., 2008; Lobell et al., 2008). Strategies that make economic sense to the farmers but at the same time ensure that crop productivity is not compromised are therefore needed. 
Agronomic practices aiming at reducing moisture stress offer greater potential benefits to improving crop productivity in rain-fed agriculture compared to improved crop varieties (Lobell, 2009). Ecological farming practices which include application of organic fertilizers i.e. manures and compost and intercropping or rotation with legumes have been proven to be successful in improving the physical properties of soil (Weil \& Magdof, 2004; Altieri, Rosset, \& Thrupp, 1998). These practices also improve yields through enhancement of the occurrence of mycorrhizal associations which have positive effects on water uptake ability of crops and their capacity to withstand drought (Syliva \& Williams, 1992; Mäder, Edenhofer, Boller, Wiemken, \& Niggli, 2000).

Drought resistant crops such as cassava and sorghum which are highly adaptable to the harsh environments of the ASALs (El-Sharkawy, 2003; Dicko, Gruppen, Traore, Voragen, \& Berker, 2005) when grown using organic fertilizers (Kihanda \& Gichuru, 1999) and integrating legumes in production increase crop yields. This is in addition to improvement of the physical, chemical and biological properties of the soil (Haque, Powell, \& Ehui, 1995; SIWI, 2001). Application of organic inputs and use of legumes in rotation or intercropping are thus practices which are instrumental in building up soil organic matter. Organic matter has desirable effects on physical properties of soil including improving the structure which translates into better infiltration capacity, higher and longer moisture storage capacity and improving overall resistance of soil to drought and erratic rainfall (Makumba et al., 2006; Rilley, Pommeresche, Eltun, Hansen, \& Korsaeth, 2008).

Though it has been previously demonstrated that intercropping, rotation and use of organic inputs can result in increased soil moisture status and yield, there is still scarce information on the combined comparative advantages of intercropping and crop rotation with application of different organic inputs in the ASALs. The purpose of the study was therefore to assess the influence of different cropping systems and organic inputs on soil moisture and yields of sorghum and cassava in semi-arid Yatta sub-County.

\section{Materials and Methods}

\subsection{Study Site}

On-farm trials were conducted in Katangi and Ikombe divisions of Yatta sub-county of Machakos County, which lies in agro-ecological zone IV classified as semi-arid (Jaetzhold, Schmidt, Hornetz, \& Shisanya, 2006). The study was conducted for 2 years (from October 2010 to August 2012) which constituted of four seasons of experimentation. The two seasons in a year are the short rain season (SRS) occurring from October to December and long rain season (LRS) from March/April to May (Table 1).

Table 1. Total rainfall $(\mathrm{mm})$ received during the four continuous seasons of field experiment

\begin{tabular}{ccccccccccccc}
\hline Season & \multicolumn{3}{c}{ Short Rain Season } & \multicolumn{2}{c}{$*$ Dry period } & \multicolumn{3}{c}{ Long Rain Season } & \multicolumn{4}{c}{$*$ Dry period } \\
\hline YEAR/Month & Oct & Nov & Dec & Jan & Feb & Mar & Apr & May & Jun & Jul & Aug & Sep \\
2010 & 15.30 & 411.40 & 112.70 & 35.70 & 3.00 & 206.10 & 294.60 & 1.00 & 4.20 & 1.00 & 0.00 & 0.00 \\
2011 & 0.00 & 164.30 & 7.00 & 103.60 & 33.20 & 65.40 & 20.00 & 5.20 & 0.00 & 0.00 & 128.60 & 0.00 \\
2012 & 26.50 & 306.20 & 196.50 & 0.00 & 0.00 & 0.00 & 176.00 & 7.80 & 0.00 & 0.00 & 12.50 & 0.00 \\
\hline
\end{tabular}

*Dry period with intermittent and far apart and/or no rains.

The soils of the study area mainly consist of Ferric Luvisols, Lithisols and Rhodic Ferralsols (Sombroek, Braun, \& Van der Pouw, 1982) with nitrogen, phosphorous and organic matter being the main limiting nutrients (Jaetzhold, Schmidt, Hornetz, \& Shisanya, 2006). Soil properties prior to experimental set-up in Katangi were: of clay texture, moderate bulk density (Hazelton \& Murphy, 2007), moderate organic C (OC), low Nitrogen, high Potassium and moderate in Phosphorus (Table 2) according to Landon (1991). For Ikombe, the initial soil properties were: sandy clay loam texture, low bulk density (Hazelton \& Murphy, 2007), low OC, low nitrogen, high phosphorous and moderate potassium (Table 2) (Landon, 1991). 
Table 2. Initial physical and chemical soil properties at the experimental sites

\begin{tabular}{lll}
\hline Soil properties & Katangi & Ikombe \\
\hline Bulk density $\left(\mathrm{g} \mathrm{cm}^{-3}\right)$ & 1.36 & 1.11 \\
Sand $(\%)$ & 40 & 58 \\
Silt $(\%)$ & 17 & 19 \\
Clay $(\%)$ & 43 & 23 \\
Textural class & Clay & Sandy clay loam \\
$\mathrm{pH}\left(\mathrm{H}_{2} \mathrm{O}\right)$ & 6.31 & 6.49 \\
$\mathrm{pH}\left(\mathrm{CaCl}_{2}\right)$ & 5.67 & 5.89 \\
$\mathrm{EC}\left(\mathrm{ds} \mathrm{m}^{-1}\right)$ & 0.2 & 0.2 \\
$\mathrm{C}(\%)$ & 1.17 & 0.74 \\
$\mathrm{~N}(\%)$ & 0.18 & 0.09 \\
$\mathrm{Na}(\mathrm{cmol} \mathrm{kg}$ & 0.38 & 0.38 \\
$\left.\mathrm{~K}(\mathrm{cmol} \mathrm{kg})^{-1}\right)$ & 0.98 & 0.75 \\
$\mathrm{CEC}(\mathrm{cmol} \mathrm{kg})$ & 20.1 & 8.1 \\
$\mathrm{P}(\mathrm{ppm})$ & 5.25 & 26.25 \\
\hline
\end{tabular}

\subsection{Treatments and Experimental Design}

The treatments consisted of three cropping systems and two organic inputs with a control. The cropping systems were monocropping, intercropping and rotation of sorghum and cassava (test crops) with either dolichos or pigeon pea. Organic inputs used were compost and Farmyard manure (FYM) and a control with no organic input applied. This resulted in fifteen treatment combinations for each test crop (Table 3). All crops had above ground biomass incorporated after harvest in the same plot they were harvested from.

Table 3. Treatments in the trial fields

\begin{tabular}{|c|c|c|c|}
\hline & Treatment No. & Cropping system & Organic input \\
\hline \multirow[t]{3}{*}{ Monocrop } & 1 & Sorghum or Cassava & FYM \\
\hline & 2 & Sorghum or Cassava & Compost \\
\hline & 3 & Sorghum or Cassava & Control \\
\hline \multirow[t]{6}{*}{ Rotation } & 4 & Pigeon pea- Sorghum or Cassava rotation & FYM \\
\hline & 5 & Pigeon pea-Sorghum or Cassava rotation & Compost \\
\hline & 6 & Pigeon pea-Sorghum or Cassava rotation & Control \\
\hline & 7 & Dolichos-Sorghum or Cassava rotation & FYM \\
\hline & 8 & Dolichos-Sorghum or Cassava rotation & Compost \\
\hline & 9 & Dolichos-Sorghum or Cassava rotation & Control \\
\hline \multirow[t]{6}{*}{ Intercropping } & 10 & Sorghum or Cassava intercropped with pigeon pea & FYM \\
\hline & 11 & Sorghum or Cassava intercropped with pigeon pea & Compost \\
\hline & 12 & Sorghum or Cassava intercropped with pigeon pea & Control \\
\hline & 13 & Sorghum or Cassava intercropped with Dolichos & FYM \\
\hline & 14 & Sorghum or Cassava intercropped with Dolichos & Compost \\
\hline & 15 & Sorghum or Cassava intercropped with Dolichos & Control \\
\hline
\end{tabular}


The experimental setup was a Randomized Complete Block Design with a split plot arrangement replicated three times. The main plots $(10 \mathrm{~m} \times 10 \mathrm{~m})$ were the cropping systems while the split-plots $(3 \mathrm{~m} \times 10 \mathrm{~m})$ were organic inputs each applied at the rate of $5 \mathrm{tha}^{-1}$ (Figure 1).

\begin{tabular}{|c|c|c|c|c|c|c|}
\hline \multirow{2}{*}{ Cropping system } & \multirow{2}{*}{ Description } & \multirow{2}{*}{ Crops } & \multicolumn{2}{|l|}{2010} & 2011 & 2012 \\
\hline & & & SRS & LRS & SRS & LRS \\
\hline \multirow{2}{*}{ Monocrop } & Sorghum monocrop & Sorghum & & & & \\
\hline & Cassava monocrop & Cassava & & & & \\
\hline \multirow{8}{*}{ Rotation } & \multirow{2}{*}{ Dolichos-sorghum rotation } & Dolichos & & & & \\
\hline & & Sorghum & & & & \\
\hline & \multirow{2}{*}{ Pigeon pea-sorghum rotation } & Pigeon pea & & & & \\
\hline & & Sorghum & & & & \\
\hline & \multirow{2}{*}{ Dolichos-cassava rotation } & Dolichos & & & & \\
\hline & & Cassava & & & & \\
\hline & \multirow{2}{*}{ Pigeon pea- cassava rotation } & Pigeon pea & & & & \\
\hline & & Cassava & & & & \\
\hline \multirow{8}{*}{ Intercropping } & \multirow{2}{*}{ Dolichos/ sorghum intercrop } & Dolichos & & & & \\
\hline & & Sorghum & & & & \\
\hline & \multirow{2}{*}{ Pigeon pea/ sorghum intercrop } & Pigeon pea & & & & \\
\hline & & Sorghum & & & & \\
\hline & Dolichos/cassava intercrop & Dolichos & & & & \\
\hline & & Cassava & & & & \\
\hline & \multirow{2}{*}{ Pigeon pea /cassava intercrop } & Pigeon pea & & & & \\
\hline & & Cassava & & & & \\
\hline
\end{tabular}

Figure 1. Cropping sequence during the four continuous seasons of field experiment

Notes: 1 . SRS $=$ short rain season, $\mathrm{LRS}=$ long rain season.

\subsection{Field Practices}

Primary land preparation was done using oxen plough and thereafter hand hoes were used during secondary cultivation. About $15 \mathrm{~kg}$ of FYM and compost (Table 4) were applied in each subplot directly into the planting holes translating into a rate of $5 \mathrm{tha}^{-1 .}$

Table 4. Initial chemical characteristics of compost and FYM used during the experimental period

\begin{tabular}{ccccc}
\hline \multirow{2}{*}{ Organic input properties } & \multicolumn{4}{c}{ Organic Inputs and Quantity applied } \\
\cline { 2 - 5 } & FYM & Quantity applied $\left(\right.$ tha $\left.^{-1}\right)$ & COMPOST & Quantity applied (tha $\left.{ }^{-1}\right)$ \\
\hline $\mathrm{N}(\%)$ & 2.71 & 0.136 & 2.55 & 0.1275 \\
$\mathrm{P}(\%)$ & 1.01 & 0.051 & 0.74 & 0.037 \\
$\mathrm{~K}(\%)$ & 3.9 & 0.195 & 1.81 & 0.091 \\
$\mathrm{OC}(\%)$ & 35 & 1.75 & 35.60 & 1.78 \\
pH ( $\left.\mathrm{H}_{2} \mathrm{O}\right)$ & 8.6 & & 9.26 & \\
$\mathrm{C}: \mathrm{N}$ Ratio & 12.92 & & 13.96 & \\
\hline
\end{tabular}


Planting of the crops was done manually by direct placement of the seeds/cuttings into planting holes. Cassava (cv. Muceliceli), sorghum (cv. Gandam), pigeon pea (cv. KAT 60/8), and dolichos (black variety) were planted with sole crops spaced at $1 \mathrm{~m} \times 1 \mathrm{~m}$ (cassava), $0.75 \mathrm{~m} \times 0.25 \mathrm{~m}$ (sorghum), $0.75 \mathrm{~m}$ by $0.3 \mathrm{~m}$ (dolichos) and 0.75 $\mathrm{m} \times 0.50 \mathrm{~m}$ (pigeon pea). All the crops for intercrop (pigeon pea or dolichos) were sown in rows between sorghum and cassava at the same inter-plant spacing as in pure stands.

During the subsequent planting seasons, land preparation was done using hand hoes. This was done to avoid mixing of organic inputs from one plot to another. Immediately after harvesting, above ground biomass of the crops were chopped into small pieces and incorporated in the same plots that they were harvested from except for cassava where the biomass was removed. This was to mimic the existing practice of removing cassava stems to be used as planting material, sold or used as firewood.

\subsection{Soil, Plant Sampling and Analysis}

Soil samples were collected within the $0.2 \mathrm{~m}$ depth using an auger. In the sorghum based cropping systems samples were collected at harvest (after 3 months). In the cassava based systems, soil sampling was done after 3 months as well as at cassava harvest (11 months). Soil moisture was determined by gravimetric method (Black, 1965).

Sorghum, dolichos and pigeon pea crops were harvested at physiological maturity (approximately 3 months after planting) from the inner $1 \mathrm{~m}^{2}$ of each subplot. Plants from the net plot area were harvested by cutting stem immediately above the ground when plants were partially dried. They were then heaped and sundried to a constant weight. The dried plants were threshed, winnowed and weighed. For cassava, harvesting was done at physiological maturity (11 months after planting) from $4 \mathrm{~m}^{2}$ area of each subplot. Hand-hoe was used to dig around the base of individual plants within the net plot area and then uprooting whole plant. Thereafter, the stem was separated from the tuber and fresh tuber weight taken using digital weighing scale. The grains and tuber of harvested crops was later extrapolated to $t \mathrm{ha}^{-1}$.

\subsection{Statistical Analysis}

Data was subjected to general analysis of variance using Genstat statistical software (Payne, Murray, Harding, Baird, \& Soutar, 2009). Treatment means were separated using the Fisher's Protected Least Significant Difference $(\mathrm{P}=0.05)$.

\section{Results and Discussions}

\subsection{Effect Cropping Systems and Organic Inputs on Soil Moisture in the Sorghum Based Cropping Systems}

In the SRS of 2010 and, LRS and SRS of 2011 there were significant interaction effects between cropping systems $\times$ organic inputs in the sorghum based cropping systems at both Ikombe and Katangi. In the LRS of 2011 however, only the main effects of cropping systems and organic inputs were significant at $\mathrm{P}=0.05$ (Tables 5 and 6). In the SRS of 2010, LRS of 2011 and SRS of 2011, sorghum/pigeon pea intercrop+FYM resulted in higher soil moisture compared to sorghum/dolichos+FYM and sorghum monocrop+FYM in both Ikombe and Katangi although the differences between sorghum/pigeon pea intercrop+FYM and sorghum/dolichos+FYM were not significant in Katangi. Similar trends between cropping systems were noted under compost application and control (Tables 5 and 6). 
Table 5. Soil moisture (\%) as affected by cropping systems and organic inputs in sorghum based cropping systems at Katangi

\begin{tabular}{|c|c|c|c|c|c|c|c|c|}
\hline \multicolumn{9}{|c|}{ KATANGI } \\
\hline \multirow{2}{*}{ Crop } & \multicolumn{3}{|c|}{ SRS 2010} & \multirow{2}{*}{ Mean } & \multicolumn{3}{|c|}{ LRS 2011} & \multirow{2}{*}{ Mean } \\
\hline & FYM & COMP & CTRL & & FYM & COMP & CTRL & \\
\hline Sorghum & $4.07^{\mathrm{g}}$ & $4.47^{\mathrm{ef}}$ & $3.98^{\mathrm{g}}$ & 10.93 & $5.47^{\mathrm{b}}$ & $4.90^{\mathrm{c}}$ & $4.07^{\mathrm{i}}$ & 4.81 \\
\hline Sorghum/dolichos & $5.04^{\mathrm{ab}}$ & $4.7^{\mathrm{dce}}$ & $4.48^{\text {ef }}$ & 10.93 & $5.71^{\mathrm{a}}$ & $5.36^{\mathrm{b}}$ & $4.56^{\mathrm{f}}$ & 5.21 \\
\hline Sorghum/pigeon pea & $5.21^{\mathrm{a}}$ & $4.98^{\mathrm{b}}$ & $4.91^{\mathrm{bc}}$ & 11.10 & $5.83^{\mathrm{a}}$ & $5.44^{\mathrm{b}}$ & $4.71^{\mathrm{e}}$ & 5.33 \\
\hline Dolichos-Sorghum & $4.33^{\text {ef }}$ & $3.93^{\text {gh }}$ & $3.60^{\mathrm{h}}$ & 10.93 & $4.73^{\mathrm{de}}$ & $4.18^{\mathrm{hi}}$ & $4.07^{\mathrm{i}}$ & 4.33 \\
\hline Pigeon pea-Sorghum & $4.45^{\mathrm{ef}}$ & $4.03^{\mathrm{g}}$ & $3.71^{\mathrm{h}}$ & 11.12 & $4.84^{\mathrm{cd}}$ & $4.43^{\mathrm{g}}$ & $3.94^{\mathrm{j}}$ & 4.40 \\
\hline mean & 4.62 & 4.42 & 4.14 & & 5.32 & 4.86 & 4.27 & \\
\hline \multirow[t]{3}{*}{$\mathrm{LSD}^{0.05}$} & \multicolumn{8}{|c|}{ Cropping systems (CS) } \\
\hline & \multicolumn{3}{|c|}{ Organic inputs (OI) } & & & & & \\
\hline & \multicolumn{2}{|c|}{$\mathrm{CS} * \mathrm{OI}$} & 0.256 & & & & 0.127 & \\
\hline $\mathrm{CV} \%$ & & & 4.9 & & & & 3.1 & \\
\hline \multirow{2}{*}{ Crop } & \multicolumn{3}{|c|}{ SRS 2011} & & \multicolumn{3}{|c|}{ LRS 2012} & \multirow{2}{*}{ Mean } \\
\hline & FYM & COMP & CTRL & Vitcant & FYM & COMP & CTRL & \\
\hline Sorghum & $7.51^{\mathrm{d}}$ & $7.15^{\mathrm{d}}$ & $5.71^{\mathrm{e}}$ & 6.79 & 6.84 & 6.51 & 5.98 & $6.44^{\mathrm{d}}$ \\
\hline Sorghum/dolichos & $10.42^{\mathrm{abc}}$ & $10.37^{\mathrm{abc}}$ & $10.30^{\mathrm{abc}}$ & 10.36 & 9.25 & 8.73 & 8.27 & $8.75^{\mathrm{b}}$ \\
\hline Sorghum/pigeon pea & $9.92^{\mathrm{bc}}$ & $9.81^{\mathrm{bc}}$ & $9.68^{\mathrm{c}}$ & 9.80 & 8.89 & 8.22 & 7.87 & $8.33^{\mathrm{c}}$ \\
\hline Dolichos-Sorghum & $10.32^{\mathrm{abc}}$ & $10.00^{\mathrm{bc}}$ & $9.52^{\mathrm{c}}$ & 9.95 & 9.58 & 9.00 & 8.49 & $9.02^{\mathrm{b}}$ \\
\hline Pigeon pea-Sorghum & $11.00^{\mathrm{a}}$ & $10.91^{\mathrm{ab}}$ & $10.83^{\mathrm{ab}}$ & 10.91 & 10.88 & 10.50 & 10.27 & $10.55^{\mathrm{a}}$ \\
\hline mean & 9.83 & 9.65 & 9.21 & & 9.09 & $8.59^{\mathrm{b}}$ & $8.18^{\mathrm{c}}$ & \\
\hline \multirow[t]{3}{*}{$\mathrm{LSD}^{0.05}$} & \multicolumn{3}{|c|}{ Cropping systems (CS) } & & & \multicolumn{3}{|c|}{0.356} \\
\hline & \multicolumn{3}{|c|}{ Organic inputs (OI) } & & & \multicolumn{3}{|c|}{0.281} \\
\hline & \multicolumn{2}{|c|}{$\mathrm{CS} * \mathrm{OI}$} & 1.103 & & & & & \\
\hline $\mathrm{CV} \%$ & & & 15.8 & & & & 15.3 & \\
\hline
\end{tabular}


Table 6. Soil moisture (\%) as affected by cropping systems and organic inputs in sorghum based cropping systems at Ikombe

\begin{tabular}{|c|c|c|c|c|c|c|c|c|}
\hline \multirow{2}{*}{ Crop } & \multicolumn{3}{|c|}{ SRS 2010} & \multirow{2}{*}{ Mean } & \multicolumn{3}{|c|}{ LRS 2011} & \multirow{2}{*}{ Mean } \\
\hline & FYM & COMP & CTRL & & FYM & COMP & CTRL & \\
\hline Sorghum & $11.50^{\mathrm{b}}$ & $11.00^{\mathrm{c}}$ & $10.30^{\mathrm{e}}$ & 10.93 & $11.89^{\mathrm{b}}$ & $11.50^{\mathrm{c}}$ & $10.90^{\mathrm{e}}$ & 11.43 \\
\hline Sorghum/dolichos & $11.50^{\mathrm{b}}$ & $10.90^{\mathrm{cd}}$ & $10.40^{\mathrm{e}}$ & 10.93 & $11.90^{\mathrm{b}}$ & $10.60^{\mathrm{f}}$ & $10.90^{\mathrm{e}}$ & 11.13 \\
\hline Sorghum/pigeon pea & $11.90^{\mathrm{a}}$ & $11.10^{\mathrm{c}}$ & $10.30^{\mathrm{e}}$ & 11.10 & $12.30^{\mathrm{a}}$ & $11.40^{\mathrm{cd}}$ & $10.80^{\mathrm{e}}$ & 11.50 \\
\hline Dolichos-Sorghum & $11.50^{\mathrm{b}}$ & $10.90^{\mathrm{cd}}$ & $10.40^{\mathrm{e}}$ & 10.93 & $11.80^{\mathrm{b}}$ & $11.30^{\mathrm{d}}$ & $10.40^{\mathrm{g}}$ & 11.17 \\
\hline Pigeon pea-Sorghum & $11.99^{\mathrm{a}}$ & $10.95^{\mathrm{c}}$ & $10.43^{\mathrm{e}}$ & 11.12 & $11.91^{\mathrm{b}}$ & $11.45^{\mathrm{cd}}$ & $10.38^{\mathrm{g}}$ & 11.25 \\
\hline mean & 11.68 & 10.97 & 10.37 & & 11.96 & 11.25 & 10.68 & \\
\hline \multirow[t]{3}{*}{$\mathrm{LSD}^{0.05}$} & \multicolumn{8}{|c|}{ Cropping systems (CS) } \\
\hline & \multicolumn{3}{|c|}{ Organic inputs (OI) } & & & & & \\
\hline & \multicolumn{2}{|c|}{$\mathrm{CS} * \mathrm{OI}$} & 0.176 & & & & 0.155 & \\
\hline $\mathrm{CV} \%$ & & & 1.6 & & & & 2 & \\
\hline \multirow{2}{*}{ Crop } & \multicolumn{3}{|c|}{ SRS 2011} & \multirow{2}{*}{ Mean } & \multicolumn{3}{|c|}{ LRS 2012} & \multirow{2}{*}{ Mean } \\
\hline & FYM & COMP & CTRL & & FYM & COMP & CTRL & \\
\hline Sorghum & $3.58^{\mathrm{e}}$ & $3.32^{\mathrm{ef}}$ & $3.01^{\mathrm{f}}$ & 3.30 & 3.53 & 3.40 & 3.02 & $3.32^{\mathrm{d}}$ \\
\hline Sorghum/dolichos & $4.36^{\mathrm{cd}}$ & $4.29^{\mathrm{cd}}$ & $4.22^{\mathrm{cd}}$ & 4.29 & 4.40 & 3.82 & 3.70 & $3.97^{\mathrm{b}}$ \\
\hline Sorghum/pigeon pea & $5.19^{\mathrm{a}}$ & $5.05^{\mathrm{ab}}$ & $4.64^{\mathrm{bc}}$ & 4.96 & 4.83 & 4.61 & 4.30 & $4.58^{\mathrm{a}}$ \\
\hline Dolichos-Sorghum & $3.56^{\mathrm{e}}$ & $3.43^{\mathrm{e}}$ & $3.18^{\mathrm{ef}}$ & 3.39 & 3.25 & 3.15 & 3.08 & $3.16^{\mathrm{d}}$ \\
\hline Pigeon pea- Sorghum & $4.31^{\mathrm{cd}}$ & $4.24^{\mathrm{cd}}$ & $4.18^{\mathrm{cd}}$ & 4.24 & 4.12 & 3.76 & 3.58 & $3.82 b$ \\
\hline mean & 4.20 & 4.07 & 3.85 & & $4.03^{\mathrm{a}}$ & $3.75^{\mathrm{b}}$ & $3.54^{\mathrm{b}}$ & \\
\hline \multirow[t]{3}{*}{$\mathrm{LSD}^{0.05}$} & \multicolumn{3}{|c|}{ Cropping systems (CS) } & & & & 0.262 & \\
\hline & \multicolumn{3}{|c|}{ Organic inputs $(\mathrm{OI})$} & & & & 0.215 & \\
\hline & & & 0.418 & & & & & \\
\hline CV\% & & & 59.1 & & & & 50.3 & \\
\hline
\end{tabular}

Higher soil moisture when intercropping with pigeon pea could be as a result of increased shading provided by sorghum/pigeon pea intercrop which reduced evaporation from the soil surface. Ghanbari, Dahmardeh, Siahsar, and Ramroudi (2010) also observed that increased shading under intercropping caused low evaporation from the soil hence more moisture. Lower soil moisture under sorghum/dolichos intercrop compared to sorghum/pigeon pea intercrop under a given organic input could be attributed to heavy soil water usage by dolichos component. Eskandari (2012) also observed that intercrops which form intensive canopies extract more water from the soil profile resulting in a drier profile than the sole crops. Sorghum/dolichos intercrop did not significantly increase soil moisture $(P=0.05)$ compared to sorghum monocrop during the SRS of 2010 and LR of 2011 at Ikombe regardless of the organic inputs used. In the SRS of 2010, intercropping with dolichos and FYM (11.50\%) applied resulted in similar soil moisture levels as monocrop with FYM while sorghum/dolichos with compost $(10.90 \%)$ had lower soil moisture though not significantly $(\mathrm{P}=0.05)$ different to sorghum monocrop (Table 6). This could be attributed to the sandy nature of the soil which allowed more moisture depletion by the intercrop in addition to the more intensive canopy development. Miriti et al. (2012) also observed reduced soil moisture in sandy clay loam soil under cowpea/maize intercrop compared to maize monocrop suggesting that the added legume crop increased the plant density hence increasing extraction of soil water.

Rotation with legumes reduced soil moisture at Katangi in SRS of 2010 and LRS 2011 compared to monocrop. For example, during SRS of 2010 Dolichos-sorghum rotation+FYM (4.33\%) resulted in significantly lower moisture levels compared to Monocropping+FYM (4.07\%). This could have been possibly caused by the legumes in rotation utilizing moisture for development hence depleting the profile of moisture. Hoyt and Leich (1983) observed lower soil moisture in plots following legumes attributing this to moisture depletion by the 
legumes. Another reason could have been that dolichos develops ground cover more rapidly but maintain it for a shorter time hence protects the soil least at harvest (Maina et al., 2000) while Pigeon pea does not offer sufficient enough canopy to protect the soil from evaporation.

Rotating with dolichos under a given inputs had lower levels of soil moisture compared to rotating with pigeon pea probably because of the less ground cover offered by dolichos at harvest hence exposing the soil surface. Another explanation could be that dolichos might have had superior ability to deplete the rhizosphere soil moisture compared to pigeon pea. Some legumes are heavy water users and hence can heavily deplete soil moisture (Miriti et al., 2012). This is especially the case if they develop intensive canopies (Eskandari, 2012). In the LRS of 2012, it was observed that inclusion of legume into the cropping systems either in rotation or intercropped resulted in higher soil moisture regardless of the legume used at both sites. Wortman, Francis, Bernards, Drijber, and Lindquist (2012) also noted increase in soil moisture under legume based plots only in the subsequent seasons. They attributed this to improved soil physical properties such as improved water infiltration and water holding capacity. Combination of any given cropping systems with FYM application increased soil moisture content relative to compost and control respectively at both sites in SRS of 2010 and, LRS and SRS of 2011. This was probably due to improved physical properties of the soil which enhanced moisture holding ability of the soil. Other authors such as Gicheru et al. (2004); Chakraborty et al. (2010) have similarly observed increases in moisture storage with application of manure attributing this to improved physical characteristics such as soil structure, infiltration and storage capacity. Compost application has also been shown to improve the physical condition of the soil (Abdel-Rahman, 2009).

\subsection{Effect Cropping Systems and Organic Inputs on Soil Moisture in the Cassava Based Cropping Systems}

In the cassava based cropping systems, significant interaction effects between cropping systems $\times$ organic inputs occurred only at Katangi during the SRS of 2011. Main effects of cropping systems and organic inputs were observed with other seasons at both sites except at Ikombe where cropping systems and organic inputs did not have any significant effects $(\mathrm{P}=0.05)$ in SRS of 2011 and LRS of 2012 respectively (Tables 7 and 8).

During the SRS of 2010 and LRS of 2011, intercropping cassava with either pigeon pea intercrop and/or dolichos resulted in significantly higher soil moisture compared to monocropping at both sites (Tables 7 and 8). This may be due to increased shading which provided better protection to the soil surface against evaporation. Other avenues such as reduction of runoff and erosion could also have contributed to the enhanced soil moisture under intercropping. El-Swaify, Lo, Joy, Shinshiro, and Yost (1988) suggested that enhanced soil moisture when intercropping cassava with legumes could be because of reduction of runoff and erosion. Cassava/pigeon pea intercrop had lower moisture levels compared to cassava/dolichos intercrop. This may have been due to reduced canopy provided by cassava/pigeon pea intercrop compared to cassava/dolichos intercrop hence exposing the soil to evaporation. Gichangi et al. (2006) also noted that pigeon pea has a tendency to depress cassava leaf growth when the two are intercropped. 
Table 7. Soil moisture (\%) as affected by cropping systems and organic inputs in cassava based cropping systems at Katangi

\begin{tabular}{|c|c|c|c|c|c|c|c|c|}
\hline \multirow{3}{*}{ Cropping system } & \multicolumn{7}{|c|}{ KATANGI } & \multirow{3}{*}{ Mean } \\
\hline & \multicolumn{3}{|c|}{ SRS 2010} & \multirow{2}{*}{ Mean } & \multicolumn{3}{|c|}{ LRS 2011} & \\
\hline & FYM & COMP & CTRL & & FYM & COMP & CTRL & \\
\hline Cassava & 5.79 & 5.50 & 5.00 & $5.43 \mathrm{~b}$ & 6.27 & 5.93 & 5.40 & $5.87^{\mathrm{c}}$ \\
\hline Cassava/dolichos & 7.53 & 7.13 & 6.61 & $7.09 \mathrm{a}$ & 8.10 & 7.60 & 7.20 & $7.63^{\mathrm{a}}$ \\
\hline Cassava/pigeon pea & 7.53 & 7.02 & 6.42 & $6.99 \mathrm{a}$ & 7.72 & 7.48 & 6.71 & $7.30^{\mathrm{b}}$ \\
\hline Dolichos-Cassava & 5.73 & 5.41 & 5.36 & $5.50 \mathrm{~b}$ & 6.35 & 6.02 & 5.49 & $5.95^{\mathrm{c}}$ \\
\hline Pigeon pea-Cassava & 5.81 & 5.59 & 5.01 & $5.47 \mathrm{~b}$ & 6.34 & 6.01 & 5.45 & $5.93^{\mathrm{c}}$ \\
\hline mean & $6.48^{\mathrm{a}}$ & $6.13^{b}$ & $5.68^{\mathrm{c}}$ & & $6.96^{\mathrm{a}}$ & $6.61^{\mathrm{b}}$ & $6.05^{\mathrm{c}}$ & \\
\hline \multirow[t]{3}{*}{$\mathrm{LSD}^{0.05}$} & \multicolumn{2}{|c|}{ Cropping systems (CS) } & 0.228 & & & & 0.109 & \\
\hline & \multicolumn{2}{|c|}{ Organic inputs (OI) } & 0.177 & & & & 0.103 & \\
\hline & \multicolumn{3}{|c|}{$\mathrm{CS} * \mathrm{OI}$} & & & & & \\
\hline $\mathrm{CV} \%$ & & & 12.7 & & & & 8.5 & \\
\hline \multirow{2}{*}{ Crop } & \multicolumn{3}{|c|}{ SRS 2011} & \multirow{2}{*}{ Mean } & \multicolumn{3}{|c|}{ LRS 2012} & \multirow{2}{*}{ Mean } \\
\hline & FYM & COMP & CTRL & & FYM & COMP & CTRL & \\
\hline Cassava & $7.80^{\mathrm{a}}$ & $6.93^{\mathrm{ab}}$ & $6.40^{\mathrm{bc}}$ & 7.04 & 7.05 & 6.30 & 5.63 & $6.32^{\text {ba }}$ \\
\hline Cassava/dolichos & $7.05^{\mathrm{ab}}$ & $6.97^{\mathrm{ab}}$ & $6.87^{\mathrm{ab}}$ & 6.96 & 6.70 & 6.49 & 6.03 & $6.41^{\text {ba }}$ \\
\hline Cassava/pigeon pea & $6.62^{\mathrm{abc}}$ & $6.43^{\mathrm{bc}}$ & $5.59^{\mathrm{c}}$ & 6.21 & 7.35 & 7.05 & 6.73 & $7.04^{\mathrm{a}}$ \\
\hline Dolichos-Cassava & $7.07^{\mathrm{ab}}$ & $6.59^{\mathrm{abc}}$ & $5.60^{\mathrm{c}}$ & 6.42 & 5.64 & 5.44 & 5.10 & $5.39^{\mathrm{c}}$ \\
\hline Pigeon pea-Cassava & $7.35^{\mathrm{ab}}$ & $7.05^{\mathrm{ab}}$ & $6.73^{\mathrm{abc}}$ & 7.04 & 6.18 & 5.45 & 5.04 & $5.56^{\mathrm{bc}}$ \\
\hline mean & 7.18 & 6.79 & 6.24 & & $6.58^{\mathrm{a}}$ & $6.15^{\mathrm{b}}$ & $5.71^{\mathrm{c}}$ & \\
\hline \multirow[t]{3}{*}{ LSD $^{0.05}$} & \multicolumn{2}{|c|}{ Cropping systems (CS) } & 1.249 & & & \multicolumn{3}{|c|}{0.889} \\
\hline & \multicolumn{2}{|c|}{ Organic inputs $(\mathrm{OI})$} & 0.211 & & & \multicolumn{3}{|c|}{0.239} \\
\hline & \multicolumn{2}{|c|}{$\mathrm{CS} * \mathrm{OI}$} & 1.276 & & & & & \\
\hline $\mathrm{CV} \%$ & & & 25.3 & & & & 26.8 & \\
\hline
\end{tabular}


Table 8 . Soil moisture (\%) as affected by cropping systems and organic inputs in cassava based cropping systems at Ikombe

\begin{tabular}{|c|c|c|c|c|c|c|c|c|}
\hline \multicolumn{8}{|c|}{ IKOMBE } & \multirow{3}{*}{ Mean } \\
\hline \multirow{2}{*}{ Cropping system } & \multicolumn{3}{|c|}{ SRS 2010} & \multirow{2}{*}{ Mean } & \multicolumn{3}{|c|}{ LRS 2011} & \\
\hline & FYM & COMP & CTRL & & FYM & COMP & CTRL & \\
\hline Cassava & 8.10 & 7.76 & 7.44 & $7.77^{\mathrm{c}}$ & 8.60 & 8.30 & 7.20 & $8.03^{\mathrm{cb}}$ \\
\hline Cassava/dolichos & 8.73 & 8.37 & 7.95 & $8.35^{\mathrm{a}}$ & 10.30 & 9.80 & 9.20 & $8.77^{\mathrm{a}}$ \\
\hline Cassava/pigeon pea & 8.40 & 8.10 & 7.60 & $8.03^{\mathrm{b}}$ & 9.00 & 8.40 & 7.50 & $8.30^{\mathrm{b}}$ \\
\hline Dolichos-Cassava & 8.20 & 7.67 & 7.63 & $7.83^{\mathrm{cb}}$ & 8.63 & 8.29 & 7.26 & $8.06^{\mathrm{cb}}$ \\
\hline Pigeon pea-Cassava & 8.14 & 7.65 & 7.14 & $7.64^{\mathrm{c}}$ & 8.51 & 8.11 & 7.14 & $7.91^{\mathrm{c}}$ \\
\hline mean & $8.31^{\mathrm{a}}$ & $7.91^{\mathrm{b}}$ & $7.55^{\mathrm{c}}$ & & $9.01^{\mathrm{a}}$ & $8.58^{\mathrm{b}}$ & $7.66^{c}$ & \\
\hline \multirow[t]{3}{*}{$\operatorname{LSD}^{0.05}$} & \multirow{2}{*}{\multicolumn{2}{|c|}{$\begin{array}{c}\text { Cropping systems (CS) } \\
\text { Organic inputs (OI) }\end{array}$}} & 0.229 & & & & 0.372 & \\
\hline & & & 0.173 & & & & 0.148 & \\
\hline & \multicolumn{2}{|c|}{$\mathrm{CS} * \mathrm{OI}$} & & & & & 0.434 & \\
\hline $\mathrm{CV} \%$ & & & 8.6 & & & & 5.0 & \\
\hline \multirow{2}{*}{ Crop } & \multicolumn{3}{|c|}{ SRS 2011} & & \multicolumn{3}{|c|}{ LRS 2011} & \multirow{2}{*}{ Mean } \\
\hline & FYM & COMP & CTRL & & FYM & COMP & CTRL & \\
\hline Cassava & 3.91 & 3.55 & 3.02 & 3.49 & 3.58 & 3.39 & 3.03 & $3.33^{\mathrm{ab}}$ \\
\hline Cassava/dolichos & 3.73 & 3.62 & 3.46 & 3.60 & 3.75 & 3.41 & 3.21 & $3.46^{\mathrm{ab}}$ \\
\hline Cassava/pigeon pea & 3.67 & 3.45 & 2.82 & 3.31 & 3.93 & 3.66 & 3.36 & $3.65^{\mathrm{a}}$ \\
\hline Dolichos-Cassava & 3.70 & 3.41 & 2.77 & 3.29 & 3.08 & 2.71 & 2.48 & $2.76^{\mathrm{c}}$ \\
\hline Pigeon pea-Cassava & 3.93 & 3.66 & 3.36 & 3.65 & 3.31 & 3.14 & 2.89 & $3.11^{b c}$ \\
\hline mean & $3.79^{\mathrm{a}}$ & $3.54^{\mathrm{b}}$ & $3.09^{\mathrm{c}}$ & & 3.53 & 3.26 & 2.99 & \\
\hline \multirow[t]{3}{*}{ LSD $^{0.05}$} & \multicolumn{3}{|c|}{ Cropping systems (CS) } & & & \multicolumn{3}{|c|}{0.392} \\
\hline & \multirow{2}{*}{\multicolumn{2}{|c|}{$\begin{array}{l}\text { Organic inputs }(\mathrm{OI}) \\
\qquad(\mathrm{CS} * \mathrm{OI})\end{array}$}} & 0.154 & & & & & \\
\hline & & & & & & & & \\
\hline $\mathrm{CV} \%$ & & & 78.2 & & & & 57.6 & \\
\hline
\end{tabular}

Lower moisture levels occurred under rotation with both legumes compared to monocropping in LRS of 2012 at both sites though not significant in Ikombe $(\mathrm{P}=0.05)$. This could probably be because cassava had stayed in the field for longer time in the case of monocrop and had hence developed larger canopy than in the rotation system. FYM application led to higher soil moisture compared to compost and control respectively mainly due to improved physical properties of the soil brought about by the use of organic manures. Other studies (Gicheru et al., 2004; Chakraborty et al., 2010) have demonstrated improvement in physical characteristics of the soil as a result of organic input application. Soil moisture increased from SRS of 2010 through to SRS of 2011 but declined regardless of the cropping systems in LRS of 2012. In the cassava cropping systems, it was also observed that soil moisture similarly decreased in LRS of 2012 at Katangi while in Ikombe the decrease started in SRS of 2011.

Initial increase in soil moisture could be attributed to improved organic matter in the soil which increased the moisture holding capacity of soil. The decline in soil moisture in the subsequent seasons was mainly because of decline in amount of received rainfall (Table 1). Ngeve (2003) had also indicated that soil moisture is primarily determined by amount and intensity of received rainfall. During the first two seasons, plots in Katangi exhibited less moisture compared to those in Ikombe mainly because more clay $(43 \%)$ in Katangi soils could have hampered water infiltration into soil. Another reason might be that the increased rainfall could have led to more rain-drop impact on the heavier clay soil which produced crusts and retarded infiltration (Miriti, 2010). However, 
during the seasons with limited rainfall, soils in Katangi had higher moisture content compared to Ikombe probably due to the ability of the clayey soils to hold more moisture for longer periods (Rahn, 1979). Since soils with less clay retain less soil moisture, this could have been a factor that could have played a part in the more dramatic decline in soil moisture at Ikombe once the amount of rainfall received declined.

\subsection{Effect of Cropping Systems and Organic Inputs on Sorghum Grain and Cassava Tuber Yield}

Sorghum grain yields: Significant interaction effects of cropping systems and organic inputs on sorghum grain yield occurred in SRS of 2010 and LRS of 2011 in Katangi. At Ikombe, the interaction effects of cropping systems and organic inputs on sorghum grain occurred in LRS of 2011. Cropping systems did not significantly affect grain yield in LRS of 2012 and SRS of 2011 at Katangi and Ikombe respectively (Tables 9 and 10).

Table 9. Sorghum grain yields $\left(\mathrm{t} \mathrm{ha}^{-1}\right)$ as affected by cropping systems and organic inputs in Katangi

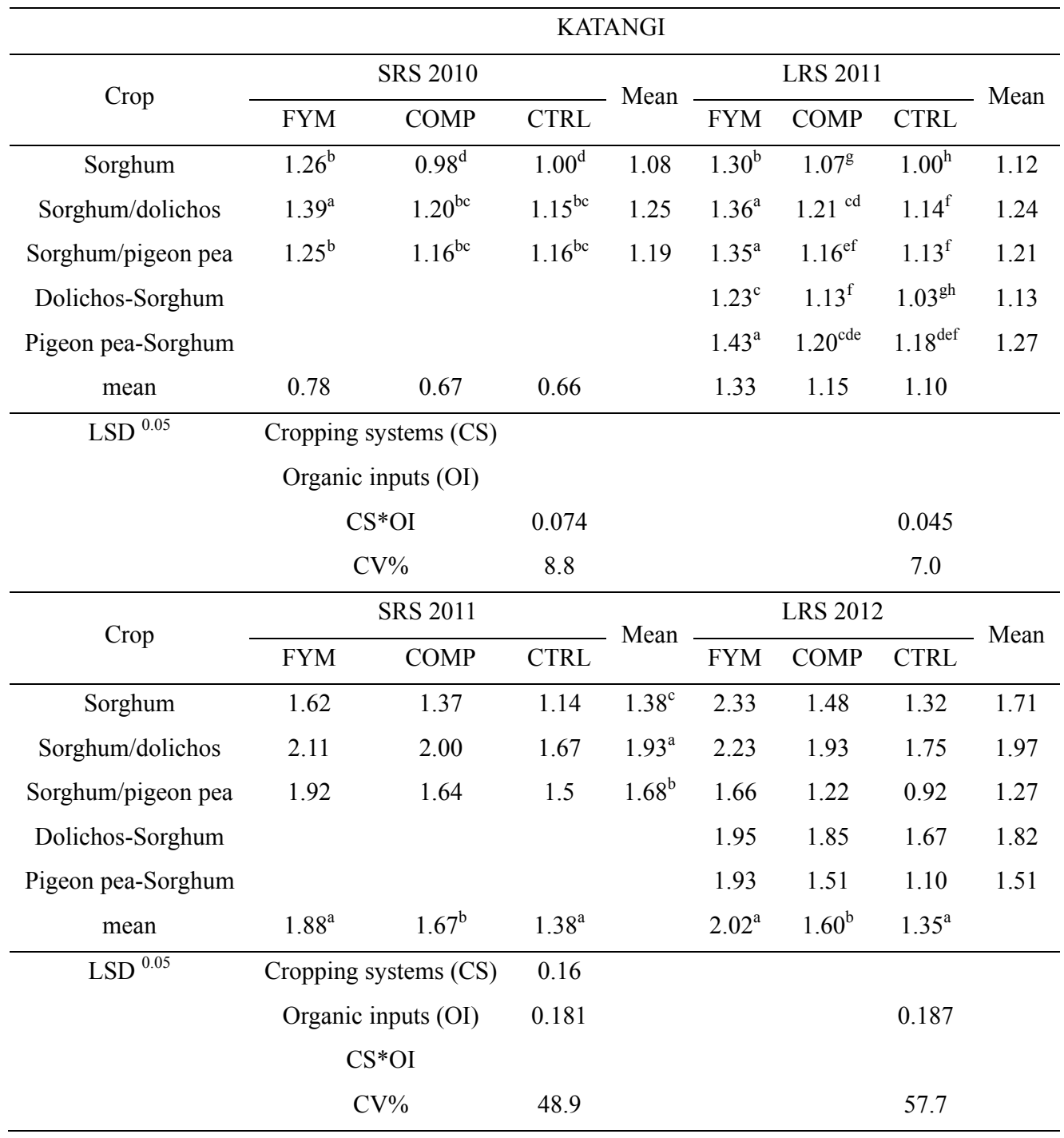


Table 10. Sorghum grain yields $\left(\mathrm{t} \mathrm{ha}^{-1}\right)$ as affected by cropping systems and organic inputs in Ikombe

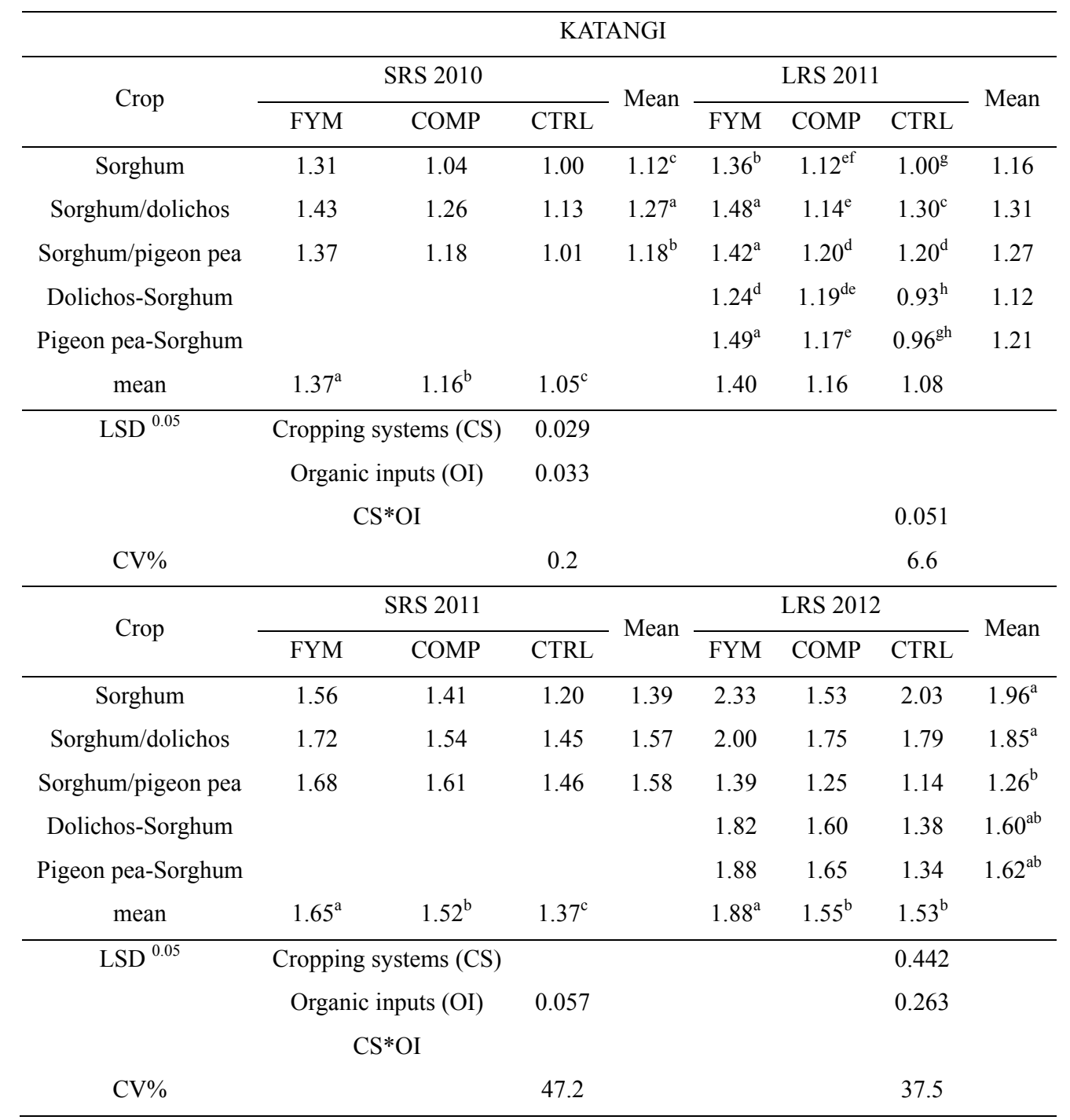

Sorghum/dolichos inetcrop+FYM significantly $(\mathrm{P}=0.05)$ increased sorghum grain yields (by $10 \%)$ relative to sorghum monocrop+FYM application in the SRS of 2010 at Katangi. Similar trends were observed under compost and control i.e. intercropping with pigeon pea and compost applied increased sorghum grain yield by 4 $\%$ at both sites while intercropping with dolichos and compost applied increased sorghum grain yields by $5 \%$ in Katangi and 9\% in Ikombe (Tables 9 and 10). The observed increase in sorghum grain yield under intercropping was contrary to expectation that sorghum grain yields would be lower under intercropping due to competition between the cereal and legume component. A possible explanation is that other factor, that may necessarily not soil dependent, could have played a greater role than competition in influencing the yield of sorghum grain. Weisskopf et al. (2009) found out that other factors such as weed suppression could be the main factors that contribute to enhanced yield of cereals in a legume/cereal intercrop. Lower sorghum yields under monocropping have also been previously observed by Kouyaté et al. (2000). They attributed this to presence of phenolic compounds in the monocropped fields which resulted in allelopathic effects causing poor germination and stand establishment. More moisture under the intercrop could have further contributed to increased grain yield of sorghum. During the SRS of 2011, rotating sorghum with either legume resulted in lower yields than intercropping with the same legume under a given input. For example, at Katangi sorghum-dolichos rotation+FYM and sorghum/dolichos intercrop+FYM resulted in grain yields of $1.36 \mathrm{t} \mathrm{ha}^{-1}$ and $1.23 \mathrm{t} \mathrm{ha}^{-1}$ respectively. This was most likely due to enhanced soil moisture that had been observed under intercropping compared to rotation. Natarajan and Willey (1986) observed that in moisture stressed environments, depression of yields could be less pronounced under intercropping compared to continuous cropping. 
It was observed that sorghum/pigeon pea intercropping had lower sorghum grain yields compared to sorghum/dolichos intercrop. For example, during the SRS of 2010 at Katangi, grain yield in sorghum/pigeon pea with FYM (1.25 t ha $\left.{ }^{-1}\right)$ was significantly lower than sorghum/dolichos with FYM (1.39). Main effects of sorghum/dolichos $\left(1.93 \mathrm{tha}^{-1}\right)$ on sorghum grain yield were significantly higher than sorghum/pigeon pea $(1.68 \mathrm{t}$ $\mathrm{ha}^{-1}$ ). In Ikombe 2010, main effects sorghum/dolichos intercrop had similarly higher sorghum grain yield (1.27 t $\left.\mathrm{ha}^{-1}\right)$ than sorghum/pigeon pea intercrop $\left(1.18 \mathrm{t} \mathrm{ha}^{-1}\right)$. This was probably due to more competition offered by pigeon pea for resources to sorghum compared to dolichos. This observation is supported by findings by Ito, Matsunaga, Tobita, Rao, and Devi (1993) who concluded that pigeon pea roots are physiologically more active compared to sorghum roots hence making the pigeon pea more competitive than sorghum when intercropped. Arshad and Ranamukhaarachchi (2012) also observed significant decline in sorghum grain yield when intercropped with soybean compared to mungbean attributing this to differences in the competitive abilities of the two legumes depending on the environment.

Application of organic inputs (FYM and/or compost) significantly $(\mathrm{P}=0.05)$ increased the yield of sorghum (Tables 9 and 10). This may be attributed to the ability of organic inputs to provide plant nutrients and increase nutrient holding capacity of soil, as well as water holding capacity and infiltration rates (Gateri, Muriuki, \& Kanyanjua, 2006; Fening et al., 2005). Higher yields were obtained under FYM application compared to Compost as a result of slower decomposition which caused longer lasting effects on soil properties (Brady \& Weil, 1996). Sorghum grain yields were significantly higher $(\mathrm{P}=0.05)$ during the SRS of 2010 compared to LRS of 2012 at both sites. Reduction in yield during the LRS of 2012 could be attributed to lower soil moisture due to lower rainfall during the LRS of 2012 compared to SRS 2010 (Table 1).

Cassava Tuber Yields: No significant effects of cropping systems $\times$ organic inputs interactions on tuber yield were observed at both sites. At Ikombe, tuber yield during the SRS of 2011 and LRS of 2012 period was not significantly affected by cropping systems. Tuber yield was significantly higher under cassava/pigeon pea compared to cassava monocrop during SRS of 2010 and LRS of 2011 at both sites (Tables 11 and 12).

Table 11. Tuber yields $\left(\right.$ tha $\left.^{-1}\right)$ as affected by cropping systems and organic inputs in Katangi

\begin{tabular}{|c|c|c|c|c|c|c|c|c|}
\hline \multirow{2}{*}{ Cropping system } & \multicolumn{3}{|c|}{ SRS 2010-LRS 2011} & \multirow{2}{*}{ Mean } & \multicolumn{3}{|c|}{ SRS 2011-LRS 2012} & \multirow{2}{*}{ Mean } \\
\hline & FYM & COMP & CTRL & & FYM & COMP & CTRL & \\
\hline Cassava & 15.02 & 14.92 & 11.1 & $13.68^{\mathrm{b}}$ & 18.85 & 14.63 & 12.47 & $15.31^{\mathrm{b}}$ \\
\hline Cassava/dolichos & 13.47 & 12.35 & 10.61 & $12.14^{\mathrm{b}}$ & 9.06 & 6.39 & 5.14 & $6.86^{\mathrm{c}}$ \\
\hline Cassava/pigeon pea & 20.77 & 18.22 & 16.92 & $18.63^{\mathrm{a}}$ & 23.53 & 18.97 & 20.06 & $20.86^{\mathrm{a}}$ \\
\hline Dolichos-Cassava & 16.36 & 12.81 & 11.74 & $13.64^{\mathrm{b}}$ & & & & \\
\hline Pigeon pea-Cassava & 18.91 & 11.88 & 10.33 & $13.70^{\mathrm{b}}$ & & & & \\
\hline mean & $16.90^{\mathrm{a}}$ & $14.03^{\mathrm{b}}$ & $12.14^{\mathrm{c}}$ & & $17.15^{\mathrm{a}}$ & $13.33^{\mathrm{b}}$ & $12.56^{\mathrm{b}}$ & \\
\hline \multirow[t]{2}{*}{$\mathrm{LSD}^{0.05}$} & \multicolumn{2}{|c|}{ Cropping systems (CS) } & 2.979 & & & & 4.902 & \\
\hline & \multicolumn{2}{|c|}{ Organic inputs (OI) } & 40.4 & & & & 44.4 & \\
\hline $\mathrm{CV} \%$ & & & 1.74 & & & & 2.636 & \\
\hline
\end{tabular}

Higher yields were observed under cassava/pigeon pea intercrop than monocrop during the SRS of 2011 and LRS of 2012 at Katangi. This may be attributed to reduction in soil fertility decline due to continuous cultivation. Cassava also tends to heavily deplete soil nutrients especially when both stems and tubers are harvested. Poor performance of continually cultivated cassava fields was observed by Fening et al. (2009) specifically in the subsequent years after the first harvest attributing this to soil fertility decline. Cong Doan Sat and Pole de Turk, (1998) and Huu Nguyen, The Dang, and Pham Van Bien (2001) found a significant deterioration in soil physical, chemical and biological properties under continuous cassava compared to other crops. 
Table 12. Tuber yields (tha ${ }^{-1}$ ) as affected by cropping systems and organic inputs in Ikombe

\begin{tabular}{|c|c|c|c|c|c|c|c|c|}
\hline \multirow{2}{*}{ Cropping system } & \multicolumn{3}{|c|}{ SRS 2010-LRS 2011} & \multirow{2}{*}{ Mean } & \multicolumn{3}{|c|}{ SRS 2011-LRS 2012} & \multirow{2}{*}{ Mean } \\
\hline & FYM & COMP & CTRL & & FYM & COMP & CTRL & \\
\hline Cassava & 22.47 & 17.04 & 11.79 & $17.10^{\mathrm{bc}}$ & 28.40 & 21.50 & 13.20 & 21.03 \\
\hline Cassava/dolichos & 19.92 & 15.81 & 11.18 & $15.64^{\mathrm{c}}$ & 38.10 & 30.60 & 14.50 & 27.73 \\
\hline Cassava/pigeon pea & 33.98 & 30.97 & 21.23 & $28.73^{\mathrm{a}}$ & 37.80 & 34.10 & 25.60 & 32.50 \\
\hline Dolichos-Cassava & 25.8 & 21.25 & 18.5 & $21.85^{\mathrm{b}}$ & & & & \\
\hline Pigeon pea-Cassava & 31.32 & 20.02 & 17.68 & $23.01^{\mathrm{ab}}$ & & & & \\
\hline mean & $26.70^{\mathrm{a}}$ & $21.02^{\mathrm{b}}$ & $16.08^{\mathrm{c}}$ & & $34.76^{\mathrm{a}}$ & $28.76^{\mathrm{b}}$ & $17.77^{\mathrm{c}}$ & \\
\hline \multirow[t]{3}{*}{ LSD $^{0.05}$} & \multicolumn{2}{|c|}{ Cropping systems (CS) } & 5.954 & & & & & \\
\hline & \multicolumn{2}{|c|}{ Organic inputs (OI) } & 4.122 & & & & & \\
\hline & \multicolumn{2}{|c|}{$\mathrm{CS} * \mathrm{OI}$} & & & & & 5.90 & \\
\hline $\mathrm{CV} \%$ & & & 35.50 & & & & 49.9 & \\
\hline
\end{tabular}

Cassava/pigeon pea intercrop resulted in higher cassava tuber yields than cassava/dolichos intercrop at both sites. This could probably be because of efficient utilization of growth resources when cassava was intercropped with pigeon pea. Dalal (1974) reported that initial slow growth of pigeon pea reduces competition for water, nutrients and light when intercropped. Polthanee et al. (1998) also observed that intercropping cassava with one row of pea nuts resulted in highest tuber yields. Similar to the case in the sorghum cropping systems, application of FYM increased tuber yield compared to compost and control respectively due to improved physical and chemical characteristics (Gateri et al., 2006; Fening et al., 2005; Brady \& Weil, 1996).

There were no significant differences in tuber yields between the two years in Katangi. At Ikombe during the SRS of 2011 and LRS of 2012, significantly higher tuber yields were observed compared to the SRS of 2010 and LRS of 2011. This was contrary to expectations that tuber yields would reduce once rainfall reduced. No robust explanation could be found for the increased yield in spite of reduced rainfall other than the initially higher rainfall received when cassava was being planted could have led to better establishment. In his review of cassava agronomy research in Asia, Howeler (2000) found that cassava yields were higher when planting was done at onset of the rainy season probably due to the need for sufficient moisture for the stakes to germinate.

\section{Conclusion}

Soil moisture and yield of cassava and sorghum varied according to cropping system, type of legume chosen and the organic input used. Soil moisture retention was higher when the two test crop (sorghum and cassava) were intercropped and FYM applied. If sorghum is to be grown, then dolichos would be applicable as an intercrop while with cassava, pigeon pea would be the ideal legume. However, yields generally followed the rainfall patterns with lower rainfall resulting in yield depression. There appears to be a mismatch between moisture content of soil and the yield. For example while cassava/dolichos intercrop had the highest moisture content it was cassava/pigeon intercrop that led to higher yields. Sorghum/dolichos intercrop had higher yields despite the highest moisture being recorded under sorghum/pigeon pea intercrop. This could suggest that moisture content alone did not determine yields of the test crops as factors like competition for the available resources also played a part. With the prime objective of maximizing yield given the limited soil moisture levels in mind, it is suggested that intercropping sorghum with dolichos and cassava with pigeon pea together with FYM application be the farming practice of choice among the smallholder farming systems of semi-arid Yatta. Further research is recommended to establish reasons why higher soil moisture did not translate into higher yields of sorghum and cassava and how the additional soil moisture could be utilized to increase productivity in the intercropping systems.

\section{Acknowledgements}

The financial support from The McKnight foundation is greatly appreciated. We thank the Agriculture extension staff from the Ministry of Agriculture and farmers in Katangi and Ikombe, Yatta Sub County for their varied contributions. We would also like to acknowledge the Soil physics and chemistry laboratory staff at the University of Nairobi, soil science laboratories for assistance in soil and plant sample analysis. 


\section{References}

Abdel-Rahman, G. (2009). Impact of compost on soil properties and crop productivity in the SahelNorthBurkinaFaso.American-Eurasian Journal of Agricultural \& Environmental Sciences, 6, 220-226.

Agili, S. M., \& Pardales, J. R. (1999). Influence of moisture and allelopathic regimes in the soil on development of cassava and mycorrhizal infection of its roots during establishment period. Philippine Journal of Crop Science, 22, 99-105.

Akram, N. A., Shahbaz, M.,\& Ashraf, M. (2008). Nutrient acquisition in differentially adapted populations of Cynodon dactylon (L.) Pers. and Cenchrus ciliaris (L.) under drought stress. Pakistan Journal of Botany, 40(4), 1433-1440.

Altieri, M. A., Rosset, P., \& Thrupp, L. A. (1998). The potential of agroecology to combat hunger in the developing world. 2020 Brief. Washington, DC, IFPRI.

Arshad, M., \& Ranamukhaarachchi, S. L. (2012). Effects of legume type, planting pattern and time of establishment on growth and yield of sweet sorghum-legume intercropping. Australian Journal of Crop Science, 6(8), 1265-1274.

Ashraf, M., Nawazish S., \& Athar, H. R. (2007). Are chlorophyll fluorescence and photosynthetic capacity potential physiological determinants of drought tolerance in maize (Zea mays L.). Pakistan Journal of Botany, 39(4), 1123-1131.

Black, C. A. (1965). Methods of Soil Analysis: Part I Physical and mineralogical properties. American Society of Agronomy. Madison, Wisconsin, USA.

Brady, N. C., \& Weil, R. R. (1996). The Nature and Properties of Soils (11th ed.). Prentice Hall, Upple Saddle River, New Jersey.

Chakraborty, D., Garg, R. N., Tomar, R. K., Dwivedi, B. S., Aggarwal, P., Singh, R., ... Singh, D. (2010). Soil physical quality as influenced by long-term application of fertilizers and manure under maize-wheat system. Soil science, 175(3), 128-136. http://dx.doi.org/10.1097/SS.0b013e3181d53bd7

Cong, D. S., \& Deturck, P. (1998). Cassava soils and nutrient management in South Vietnam. In R. H. Howeler (Ed.), Cassava Breeding, Agronomy and Farmer Participatory Research in Asia: Proceedings of the Fifth Regional Workshop (Nov. 3-8, 1996. pp.257-267). Danzhou, Hainan, China.

Dalal, R. C. (1974). Effects of intercropping maize with pigeon peas on grain yield and nutrient uptake. Environmental Agriculture, 10, 219-224.

Dicko, H., Gruppen, H., Traore, A., Voragen, J., \& Berker, J. (2005). Sorghum grain as human food in Africa. Relevance of content of starch and amylase activities. African Journal of Biotechnology, 5(5), 384-395.

El-Sharkawy, M. A. (2003). Cassava biology and physiology. Plant Molecular Biology, 53, $621-641$. http://dx.doi.org/10.1023/B:PLAN.0000019109.01740.c6

El-Swaify, S. A., Lo, A., Joy, R., Shinshiro, L., \& Yost, R. S. (1988). Achieving conservation- effectiveness in the tropics using legume intercrops. Soil Tech., 1, 1-12. http://dx.doi.org/10.1016/S0933-3630(88)80002-3

Eskandari, H. (2012). Intercropping of maize (Zea mays) with cowpea (Vigna sinensis) and mungbean (Vigna radiata): effect of complementarity of intercrop components on resource consumption, dry matter production and legumes forage quality. Journal of Basic and Applied Scientific Research, 2, 355-360.

FAO. (1996). World Food Summit. Volume 3, Technical background documents 12-15 (15-Technical Atlas, map 12). FAO, Rome.

Fening, J. O., Adjei-Gyapong, T., Yeboah, E., Ampontuah, E. O., Quansah, G., \& Danso, S. K. A. (2005). Soil fertility status and potential organic inputs for improving smallholder crop production in the interior Savannah zone of Ghana. Journal of Sustainable Agriculture and the Environment, 25(4), 69-92. http://dx.doi.org/10.1300/J064v25n04_07

Fening, J. O., Gyapong, T. A., Ababio, F., \& Gaisie, E. (2009). Effect of site characteristics on the productivity and economic returns from cassava legume intercropping in Ghana. African Journal of Environmental Science and Technology, 3(10).

Funk, C., Dettinger, M. D., Michaelsen, J. C., Verdin, J. P., Brown, M. E., Barlow, M., \& Hoell, A. (2008). Warming of the Indian Ocean threatens eastern and southern African food security but could be mitigated by agricultural development. Proceedings of the National Academy of Sciences, 105, 11081-11086. 
http://dx.doi.org/10.1073/pnas.0708196105

Gateri, M. W., Muriuki, A. W., \& Kanyanjua, S. M. (2006). Sorghum responses to inorganic fertiliser and farmyard manure in Kenya. In 10th KARI Biennial Scientific Conference, 13-17 November 2006, Nairobi, Kenya.

Ghanbari, A., Dahmardeh, M., Siahsar, B. A., \& Ramroudi, M. (2010). Effect of maize (Zea mays L.)-cowpea (Vigna unguiculata L.) intercropping on light distribution, soil temperature and soil moisture in arid environment. Journal of Food, Agriculture and Environment, 8(1), 102-108.

Gichangi, A., Maina, M. P. D., Lelgut, D. K., Kinyua, M. G., Macharia, E., Kamwaga, J., ... Luvonga, J. (2006). Cassava-Grain Legume Inter-Crop: Its Feasibility and Implications on Household Food Security in Kenya. Strengthening Kenya's food security and income. In 10th KARI Biennial Scientific Conference. Kenya Agricultural Research Institute. KARI, 12 - 17 Nov 2006 Nairobi (Kenya).

Gicheru, P., Gachene, C., Mbuvi, J., \& Mare, E. (2004). Effects of soil management practices and tillage systems on surface soil water conservation and crust formation on a sandy loam in semi-arid Kenya. Soil and Tillage Research, 75(2), 173-184. http://dx.doi.org/10.1016/S0167-1987(03)00161-2

Haque, I., Powell, J. M., \& Ehui, S. K. (1995). Improved crop-livestock production strategies for sustainable soil management in tropical Africa. In R. Lal \& B. A. Stewart (Eds.), Soil Management: Experimental Basis for Sustainability and Environmental Quality (pp. 293-345). Boca Raton: CRC Press.

Hazelton, P., \& Murphy, B. (2007). Interpreting soil test results what do all the numbers mean? (1st ed.). Collingwood, VIC: CSIRO Publishing.

Howeler, R. H. (2000). Cassava agronomy research in Asia: Has it benefited cassava farmers. Cassava's Potential in Asia in the 21st Centura: Present Situation and Future Research and Development Needs (pp. 345-382). Proc. 6th Regional Workshop. Ho Chi Minh city, Vietnam.

Hoyt, P. B., \& Leitch, R. H. (1983). Effects of forage legume species on soil moisture, nitrogen, and yield of succeeding barley crops. Canadian Journal of Soil Science, 63(1), $125-136$. http://dx.doi.org/10.4141/cjss83-012

Hy Nguyen Huu, Nguyen The Dang, \& Pham Van Bien. (2001). Cassava agronomy research and adoption of improved practices in Vietnam. In R. H. Howeler \& S. L. Tans (Eds.), Cassava's Potential in Asia in the 21st Century: Present Situation and Future Research and Development Needs (pp. 216-227). Proc. 6th Regional Workshop. Ho Chi Minh city, Vietnam.

Itabari, J. K., Nguluu, S. N., Gichangi, E. M., Karuku, A. M., Njiru, E. N., Wambua, J. M., ... Gachimbi, L. N. (2004). Managing Land and Water Resources for Sustainable Crop Production in Dry Areas. A case study of small-scale farms in semi-arid areas of Eastern, Central, and Rift Valley Provinces of Kenya. In L. Crissman (Ed.), Agricultural Research and Development for Sustainable Resource Management and Food Security in Kenya (11-12 November 2003. pp. 31-42). In Proceedings of End of Programme Conference, KARI.

Ito, O., Matsunaga, R., Tobita, S., Rao, T. P., \& Devi, Y. G. (1993). Spatial distribution of root activity and nitrogen fixation in sorghum/pigeonpea intercropping on an Indian Alfisol. Plant and soil, 155(1), 341-344. http://dx.doi.org/10.1007/BF00025052

Jaetzhold, R., Schmidt, H., Hornetz, B., \& Shisanya, C. (2006). Farm management handbook of Kenya (Vol II Subpart C1, II). Eastern province. Natural Conditions and Farm Management Information. Ministry of Agriculture, Nairobi, Kenya.

Kihanda, F. M., \& Gichuru, M. (1999). Manure management for soil fertility improvement. KARI and TSBF, Nairobi.

Kinama, J. M., Stigter, C. J., Ong, C. K., Ng'ang'a, J. K., \& Gichuki, F. N. (2005). Evaporation from soils below sparse crops in contour hedgerow agroforestry in semi-arid Kenya. Agricultural and forest meteorology, 130(3), 149-162. http://dx.doi.org/10.1016/j.agrformet.2005.03.007

Kouyaté, Z., Franzluebbers, K., Juo, A. S., \& Hossner, L. R. (2000). Tillage, crop residue, legume rotation, F green manure effects on sorghum and millet yields in the semiarid tropics of Mali. Plant and Soil, 225(1-2), 141-151. http://dx.doi.org/10.1023/A:1026589528352

Landon, J. R. (1991). Booker Tropical Soil Manual (1st ed.). A Handbook of Soil Survey and Agricultural Land Evaluation in the Tropics and Sub-Tropics. Longman, London.

Lawson, T. L., \& Sivakumar, M. V. K. (1991). Climatic constraints to crop production and fertilizer use. In A. 
Uzo Mokwunye (Ed.), Alleviating soil fertility con-straints to increased crop production in West Africa. Dordrecht: Kluwer Academic Publishers. http://dx.doi.org/10.1007/978-94-011-3224-4_4

Lobell, D. B, Burke, M. B, Tebaldi, C., Mastrandrea, M. D., Falcon, W. P., \& Naylor, R. L. (2008). Prioritizing climate change adaptation needs for food security in 2030. Science, 319, 607-610. http://dx.doi.org/10.1126/science.1152339

Lobell, D. B. (2009). Climate Extremes and Crop Adaptation. Summary statement from a meeting at the program on Food Security and Environment. Stanford, CA, held on June 16-18, 2009. Retrieved from $\mathrm{http}$ //foodsecurity.stanford.edu/publications/climate_extremes_and_crop_adaptation/

Mäder, P., Edenhofer, S., Boller, T., Wiemken, A., \& Niggli, U. (2000). Arbuscular mycorrhizae in a long-term field trial comparing low-input (organic, biological) and high-input (conventional) farming systems in a crop rotation. Biology and Fertility of Soils, 31, 150-156. http://dx.doi.org/10.1007/s003740050638

Maina, J. M., Mburu, M. W. K., Mureithi, J. G., Gachene, C. K. K., Mburu, J. N., Ngugi, J. N., \& Kimemia, J. K. (2000). Evaluation of legumes as cover crops for soil and weed management in smallholder coffee cropping systems in central Kenya.

Makumba, W., Janssen, B., Oenema, O., Akinnifesi, F. K., Mweta, D., \& Kwesiga, F. (2006). The long-term effects of a gliricidia-maize intercropping system in Southern Malawi, on gliricidia and maize yields, and soil properties. Agriculture, Ecosystems \& Environment, $116, \quad 85-92$. http://dx.doi.org/10.1016/j.agee.2006.03.012

Miriti, J. M. (2010). Effects of conservation tillage on soil properties, moisture conservation and yield of maize and cowpea in semi-arid Eastern Kenya. Doctoral dissertation, University of Nairobi, Kenya.

Miriti, J. M., Kironchi, G., Esilaba, A. O., Heng, L. K., Gachene, C. K. K., \& Mwangi, D. M. (2012). Yield and water use efficiencies of maize and cowpea as affected by tillage and cropping systems in semi-arid Eastern Kenya. Agricultural Water Management, 115, 148-155. http://dx.doi.org/10.1016/j.agwat.2012.09.002

Natarajan, M., \& Willey, R. W. (1986). The effects of water stress on yield advantages of intercropping systems. Field Crops Research, 13, 117-131. http://dx.doi.org/10.1016/0378-4290(86)90015-8

Ngeve, J. M. (2003). Cassava root yields and culinary qualities as affected by harvest age and test environment. Journal of the Science of Food and Agriculture, 83(4), 249-257. http://dx.doi.org/10.1002/jsfa.1307

Payne, R. W., Murray, D. A., Harding, S. A., Baird, D. B., \& Soutar, D. M. (2009). GenStat for Windows (12th ed., p. 310). Introduction. VSN International, Hemel Hempstead, UK.

Polthanee, A., Wanapat, S., \& Mangprom, P. (1998). Row arrangement of peanut in cassava-peanut Intercropping: II Nutrient removal and nutrient balance in soil. Khon Kaen Agric. J., 26(3), 125-131.

Rahn, J. J. (1979). Making the Weather Work for You (p. 2). A Practical Guide for Gardener and Farmer. Garden Way Publishing. Charlotte, Vermont.

Rilley, H., Pommeresche, R., Eltun, R., Hansen, S., \& Korsaeth, A. (2008). Soil structure, organic matter and earthworm activity in a comparison of cropping systems with contrasting tillage, rotations, fertilizer levels and manure use. Agriculture, Ecosystems \& Environment, 124, 275. http://dx.doi.org/10.1016/j.agee.2007.11.002

SIWI. (2001). Water harvesting for upgrading of rainfed agriculture. In J. Rockström, P. Fox, G. Persson \& M. Falkenmark (Eds.), Problem analysis and research needs (SIWI Report No 11). Stockholm, Sweden.

Sombroek, W. G., Braun, H. M. H., \& Van der Pouw., B. J. A. (1982). Exploratory soil map and agro-climatic zone map of Kenya, 1980. Scale 1: 1,000,000. Kenya Soil Survey.

Sylvia, D. M., \& Williams, S. E. (1992). Vesicular-arbuscular mycorrhizae and environmental stress. Mycorrhizae in sustainable agriculture, (mycorrhizaeinsu), 101-124.

Weil, R., \& Magdoff, F. (2004). Significance of soil organic matter to soil quality and health. In F. Magdoff \& R. Weil (Eds.). Soil Organic Matter in Sustainable Agriculture (pp. 1-43). CRC Press, Boca Raton, FL. http://dx.doi.org/10.1201/9780203496374.ch1

Weisskopf, L., Akello. P., Milleret, R., Khan, Z. R., Schulthess, F., Gobat, J., \& Le Bayon, R. (2009). White lupin leads to increased maize yield through a soil fertility-independent mechanism: a new candidate for fighting Striga hermonthica infestation? Plant Soil, 319, 101-114. http://dx.doi.org/10.1007/s11104-008-9853-4

Wortman, S. E., Francis, C. A., Bernards, M. L., Drijber, R. A., \& Lindquist, J. L. (2012). Optimizing cover crop 
benefits with diverse mixtures and an alternative termination method. Agronomy Journal, 104(5), 1425-1435. http://dx.doi.org/10.2134/agronj2012.0185

\section{Copyrights}

Copyright for this article is retained by the author(s), with first publication rights granted to the journal.

This is an open-access article distributed under the terms and conditions of the Creative Commons Attribution license (http://creativecommons.org/licenses/by/3.0/). 